伯水 英夫

第一製薬(株)・代謝分析研究所

\title{
REPORT ON QUESTIONNAIRES TO COMPANIES IN JPMA
}

Hideo Hakusui

Daiichi Pharmaceutical C0., LTD. Drug Metabolism \& Analytical Chemistry Research Laboratory

\section{[はじめに $]$}

I C Hのハーモナイゼーションが進み、 T K および反復投与分布試験ガイダンス が実施直前である事、薬物相互作用への 対応が急務である事等から、現行「薬物 動態試験ガイドライン」の見直しが検討 される状況にある。製薬協・第 4 分科会

（薬物動態）では本年 3 月から 6 月にか けて、加盟各社に現行薬物動態試験ガイ ドラインの見直しに関するアンケートを 実施した。結果の概要を報告する。

[アンケート結果］

1. 現行「薬物動態試験ガイドライン」の 存在について

A D M E 試験を実施する上での基本的 な考え方や方向性を簡潔に示しており、 存在意義は高く評価されている。一方、 その後の状況変化に対応するために改訂 の希望も強く (100\%)、改訂内容について は一部内容之(約70\%)、大幅改訂(約 $30 \%)$ とに意見が分かれた。

2. 現行ガイドラインの利点

1)薬物動態試験の研究内容を極めて端的 に網羅しており全体像をつかむために有 用である。2)申請に必要な試験項目を組 立てやすく開発研究を計画的に実施出来 る。3）その他、各社の試験内容が統一化 され得る等の回答があった。

3. 現行ガイドラインの問題点
1）ヒト薬物動態研究に関する記載が必要 との指摘が最も多く、次いで、2)代謝研 究の進歩に追従して、被験薬の代謝に関 与するP-450分子種の同定と、それに基づ く薬物相互作用の検討が必要であるとの 指摘も多かった。その他、3）I C H 合意 ガイダンス ( $\mathrm{T} \mathrm{K}$ ，反復投与分布試験) と の整合性に留意する必要がある。国際的 な調和も必要である。4)ガイドラインと 「申請資料概要」作成要領との整合性を とり、ガイドラインには必要最小限の試 験項目を再検討して載せ、フレキシブル な運用が必要等の意見が多かった。

4. 現行ガイドラインの具体的改訂点

1)序文：TKおよび反復投与分布試験ガ イダンスとの関連性およびヒトにおける 薬物動態試験とのかかわりを明記する必 要がある。2)試験方法：投与間隔、投与 期間 $; \mathrm{TK}$, 反復投与分布試験之の対応 が必要となる。定量法 ; T Kでのバリデ ーションと同程度の記載が必要。3)吸収 : 線形性；TKデータの活用。吸収に及 す影響; 再検討必要、動物で検討しても 無意味では。4)分布： ARG ; ラジオルミノ グラフィーによる定量も組織濃度デー夕 として採用する(両方の必要性を削除する )。蓄積性 ; 反復投与分布試験で評価す る。5)代謝 : P-450 ; 研究の進歩を踏まえ 、代謝に関与している分子種を同定する。 
ヒト; ヒト肝代謝酵素試験系を用いた 代謝研究を実施する。薬物相互作用; 基 本的な実施項目記載。F D A ガイダンス のように目的に合わせて個別にガイドラ インを制定した方が良いとの意見もあっ た。6)排泄：腸肝循環 ; 実施について再 検討必要。排泄への影響要因 ; 動物での 検討は意味が薄い。7) その他の検討項目 及び留意点：蛋白製剤、バイオ医薬品；

これらについても記載が欲しい。実施の タイミング；臨床試験移行に必要な試験 項目を明確にして欲しい。蛋白結合、ラ セミ体; 検討項目を明確にして欲しい。 8) (注)：注 1 ; RI標識体の合成法の記述 は不要。注 9 ; 年齢、病態を省く。

5. 将来の在り方

1)国際化の観点から：欧米に近いガイド ラインにすべきである(欧米化)、または 国際的に通用するガイドラインにすべき である(国際化への配慮)との意見が多く 一方、少数意見として、国際的統一化は 困難であり詳細な記載のある日本のガイ ドラインを継続して欲しい(日本化)との 意見もあった。2）ヒトでの薬物動態試験 実施の観点から：臨床薬物動態試験の重 要性; ヒトについても含めるべき、ヒト 主体にして改正すべき、ヒトに関するも のを別途作成すべきとの意見があった。 ヒトでの試験内容; ヒト組織 $(\mathrm{P}-450$ を含 む)を用いる代謝研究は欧米の実情から みても必須であり行政側の支援が必要で あると言う意見が多い。一方、日本でヒト 肝組織の入手が困難である事からガイド ラインに入れないほうが良いとする少数 意見もあった。RI標識体を用いたヒト試 験を実施すべきであり、法整備が必要と の意見もあった。3)ガイドラインの位置 づけ役割：申請に限定；おくまでも申請
の試験之「資料概要」作成要領の手引き として位置づけられるべきである。 Case by Case ; 薬物動態試験は毒性、薬効の 結果解析、研究のデザインに必要性があ り、客観性を保証するための毒性、臨床 ガイドラインとは性格が異なる。薬物毎 のフレキシブルな対応ができるよう、考 え方のみを簡潔に述べたものを希望する。 申請方式 ; ガイドラインだけでなく解説 書および「資料概要」作成要領の改定も 忘れてはならない。当局との相談制度( I ND方式)の確立が望まれる。役割; 探 索step 亡開発stepで薬物動態研究の創薬 での役割は異なる。探索stepでは候補品 の動態面からの評価とヒトにおける動態 予測が主であり、ここにガイドラインの 入る余地はない。開発stepはレギュレー ションへの対応が大部分であり、ここの 部分には必要性がある。

[ま亡め]

現行ガイドラインが新薬開発に果たし た役割は大きいと評価されるが、研究技 術の著しい進歩、I C Hの合意に基づく 新ガイドラインの設定等から、その改訂 が強く望まれている。薬物動態試験の新 薬開発における役割が、非臨床薬効・毒 性試験結果のヒトでの予測、評価、確認 にある以上、現行ガイドラインに欠けて いるヒトでの薬物動態試験重視の要望は 当然と言える。 $\mathrm{T} \mathrm{K}$ 試験、反復投与分布 試験ガイダンスの実施を踏まえての毒性 - 薬効評価との新しい連携、代謝研究の 進歩を踏まえての薬物相互作用の検討も 必要視されている。薬物動態は被験薬物 毎に、また被験動物毎に大きく異なるの が本質であり、ガイドラインには詳細な 記述を避けて、基本方針が明示され、フレ キシブルに運用できる事が望まれている。 